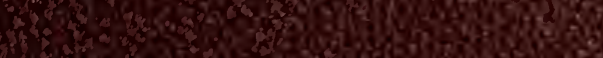
(15)

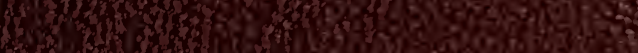
3. 3

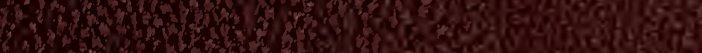

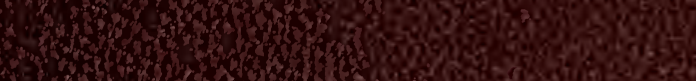

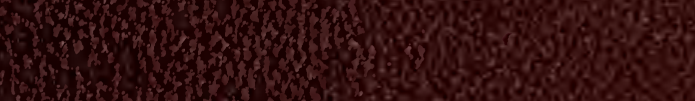

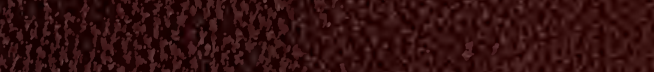

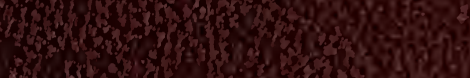
3.7. W. X.t.

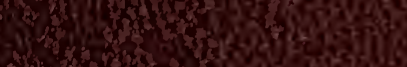
Hor 0

W. $3 \times$. 5 . m.

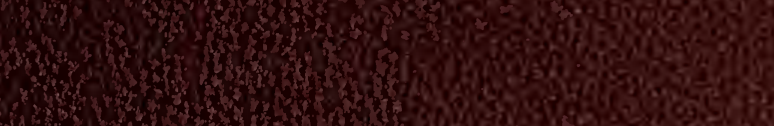

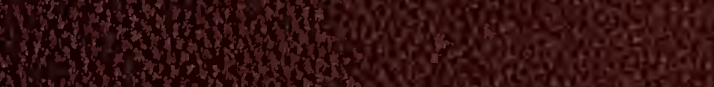

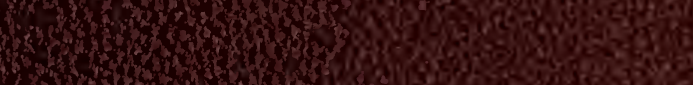

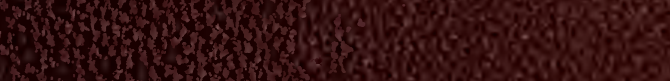

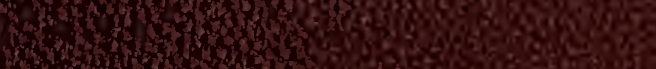

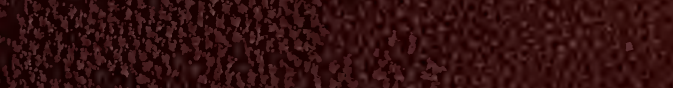

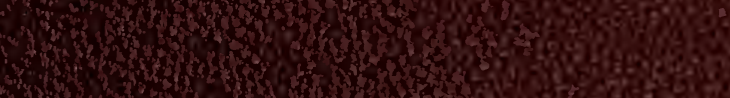

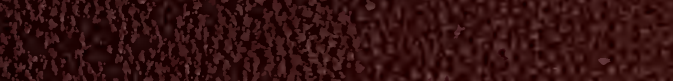
How

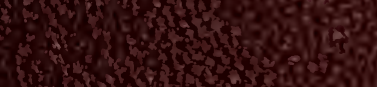

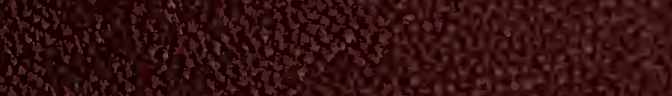
H.

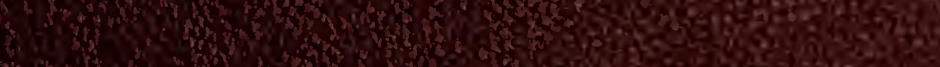

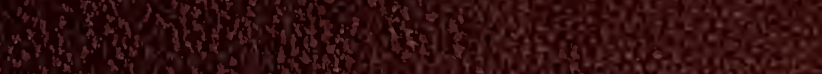

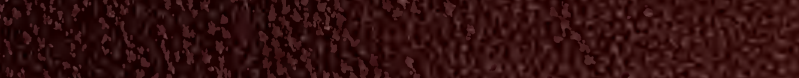
A. 3 s.

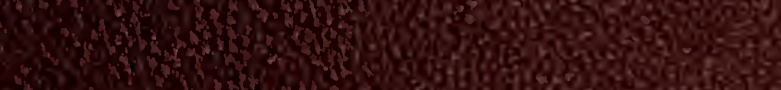
H.

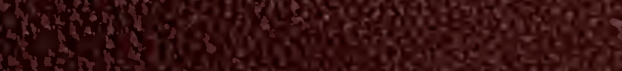
ring

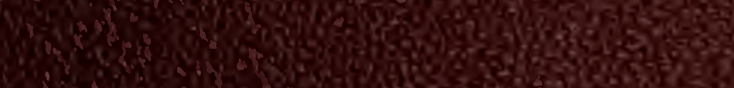

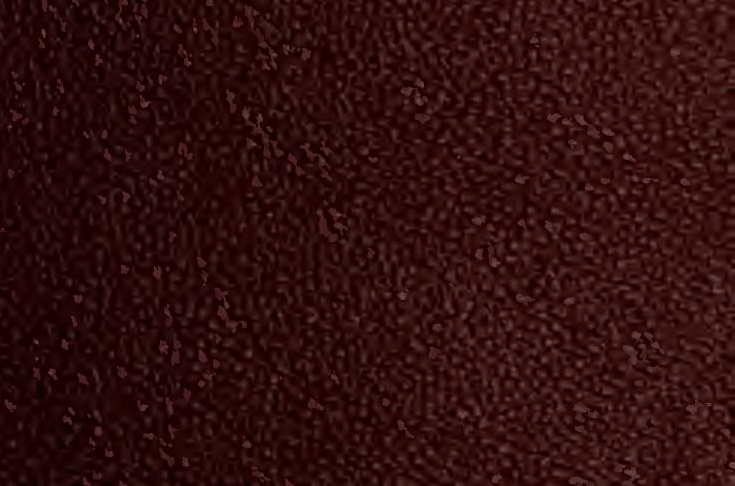





\section{CAPE SABLE REGION OF FLORIDA}

JOHN K. SMALL

NEW YORK

1919

\section{Cols Works}

LIBRARY OF 'IHE GRAY HERBARIUM

Sim 1

HARVARI) UNIVERSITY

THE GIFT (OF

16 B.L. Robinson 

Digitized by the Internet Archive in 2014

https://archive.org/details/capesableregiono00smal 

THE CAPE SABLE REGION OF FLORIDA

JOHN K. SMALL 
PRESS OF
THE NEW ERA PRINTING COMPANY
LANCASTER, PA. 


\section{PREFACE}

My introduction to the flora of Florida occurred in the fall of I90I when I assisted in securing specimens of the native and exotic plants of southern Florida for cultivating in the conservatories of the New York Botanical Garden, then lately completed. This experience, following a decade of study on the plant specimens previously collected in that state and preserved in the herbarium of Columbia University, decided me to devote what time I could command to the botanical exploration of Florida.

In the fall of 1903 field-work was begun. Since then it has been continued mainly as periods of vacation became available, at first with aid from the New York Botanical Garden and later under the patronage of Mr. Charles Deering.

I have visited the extremes of the state and much of the intervening territory; but vast areas, particularly the uninhabited or sparsely populated parts of the mainland, the coastal islands, and the Florida reef, are largely virgin territory.

Records of explorations have appeared in papers cited in the appended list, while various technical papers dealing with the new and rare plants, and local floras based largely on the field-work, have appeared elsewhere.

i. Report on Exploration in Tropical Florida.-Journal of the New York Botanical Garden 5: 49-53. 1904.

2. Report upon Further Exploration of Southern Florida.Journal of the New York Botanical Garden 5: 15;-164. I904. 
3. Exploration of Southern Florida.-Journal of the New York Botanical Garden 8: 23-28. I907.

4. Exploration in the Everglades.-Journal of the New York Botanical Garden 10: 48-55. I909.

5. Report on Botanical Exploration in Andros, Bahamas.Journal of the New York Botanical Garden II: 88-IoI. I9I0. (Included here on account of the relation between the flora of Florida and that of Andros.)

6. Exploration in Southern Florida.-Journal of the New York Botanical Garden I2: I47-I57. I9II.

7. Report on Exploration in Tropical Florida.-Journal of the New York Botanical Garden 14: 8I-86. I9I3.

8. Exploration in the Everglades and on the Florida Keys.' -Journal of the New York Botanical. Garden 15: 69-79. I9I4.

9. Exploration in Southern Florida in I9I5.-Journal of the New York Botanical Garden I7: 37-45. I9I6.

io. Royal Palm Hammock.-Journal of the New York Botanical Garden I7: 165-172. I9I6.

ii. A Cruise to the Cape Sable Region of Florida.-Journal of the New York Botanical Garden I7: 189-202. I9I6.

12. Botanical Exploration in Southern Florida in igi6.Journal of the New York Botanical Garden 18: 98-III. I9I7.

13. The Tree Cacti of the Florida Keys.-Journal of the New York Botanical Garden 18: 199-203. I9I7.

i4. Collecting Prickly-Pears at Apalachicola.-Journal of the New York Botanical Garden I9: I-6. I9I8.

i5. Ferns of Tropical Florida.-The American Museum Journal I8: $127-135$. I9I8.

i6. A Winter Collection Trip in Florida.-Journal of the New York Botanical Garden I9: 69-77. I9I8.

i7. Botanical Exploration in Florida in i9i7.- Journal of the New York Botanical Garden 19: 279-290. I9I8.

18. Narrative of a Cruise to Lake Okeechobee.-The American Museum Journal 18: 684-700. I9I9.

19. The Prickly-Pears of Florida.-Journal of the New York Botanical Garden 20: 2I-39. I9I9. 
20. Coastwise Dunes and Lagoons.-(A Record of Exploration in Florida in the Spring of 1918.)-Journal of the New York Botanical Garden 20: no. 237, October. 1919.

The following account of a cruise to the Cape Sable region of Florida appeared in somewhat different form in the Journal of the New York Botanical Garden in November, I916, number eleven of the above list. 



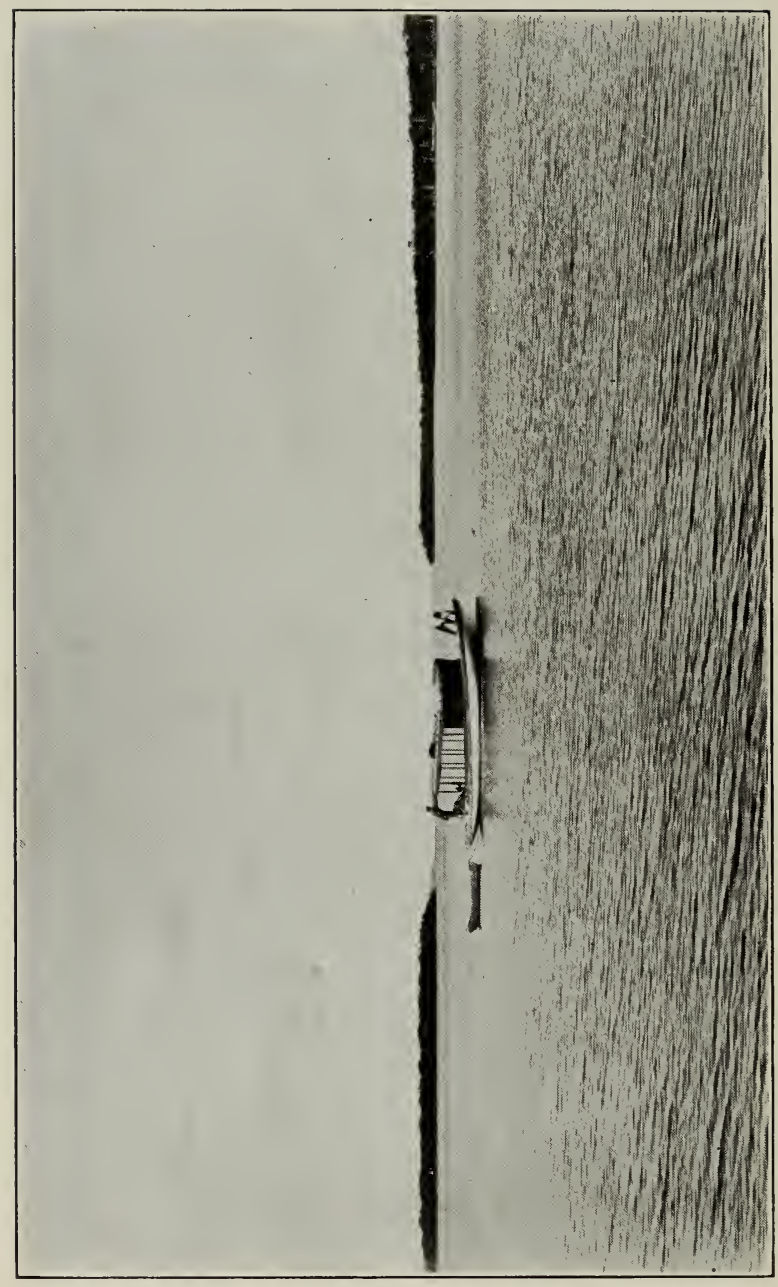

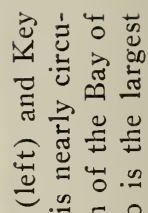

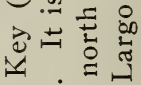

.

हิ กำ

군

ฮ

๖. $\Xi \Xi$

포

ชิ

ํㅠㅀ

- $\frac{\pi}{2}$ 는

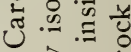

$\Xi$ ह

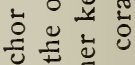

สิ $\cong$ 퓽

ส

$\therefore$ 红立

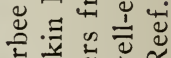

त

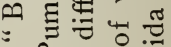

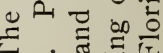

I

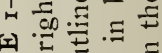

约 $匚$ ช

虫

य कั 


\section{NARRATIVE}

The geographical position of Cape Sable, lying as it does at the southern extremity of Florida, had long indicated the necessity of exploration in connection with our studies on the flora of that state. Such exploration was apt to prove especially important in a number of ways. The region was little known. No botanist had visited it since A. P. Garber, ${ }^{1}$ A. H. Curtiss, ${ }^{2}$ and J. H. Simpson ${ }^{3}$

${ }_{1}^{1}$ Abram Paschall Garber was born February 23, 1838, at Columbia, Lancaster County, Pennsylvania. He was a graduate of Lafayette College (I868), and studied medicine at the University of Pennsylvania (M.D., I872). Compelled by ill health to seek a warm climate, he went to southern Florida about 1877, and spent several years there, devoting much attention to the collection of plants in that hitherto little-known region. He also collected in Porto Rico in I880. In I88I he returned to Pennsylvania, where he died, at Renovo, in Clinton County, on the 26th of August of that year.-John Hendley Barnhart.

${ }^{2}$ Allen Hiram Curtiss, well known as a collector of the plants of the southeastern United States, was born at Central Square, Oswego County, New York, February 9, I845. His earlier collections were in Virginia, but from I875 until I901 he confined his attention very largely to Florida; his first' collections from the southern part of the peninsula seem to date from about 1880 . Beginning with 1902 , he devoted his time chiefly to collecting in the West Indies. He died at Jacksonville, Florida, September I, 1907.-J. H. B.

${ }^{3}$ Joseph Herman Simpson was born January 9, I84I, near Tiskilwa, Bureau County, Illinois. He became thoroughly familiar with the flora of Bureau County and vicinity before his removal to what is now Bradentown, Manatee County, Florida, in April, 1882. He afterward collected in various parts of southern Florida, most of his trips away from home being made in the 
touched there over a quarter of a century ago. Thus, the geographical ranges of some of our rarer native plants could be thoroughly worked out. There was good prospect of recording the presence of plants not found elsewhere and it was almost certain that new light would be thrown on the relation between the flora of southern Florida and that of the West Indies.

It was with high hopes of a profitable adventure, therefore, that the writer set out for this region early in the spring of I9I6. In passing, it may be mentioned that his hopes were largely realized.

The objects of the expedition were four, namely, studies in the distribution of plants, studies in the distribution of tree snails, the securing of a cargo of living palms and orchids, and photography. The party comprised C. T. Simpson, John Soar, Victor Soar, Paul Matthaus, and the writer.

The early morning of March 28, therefore, found the writer on board the "Barbee" as she lay off Buena Vista in Bay Biscayne. All supplies were aboard and everything was ready.

The "Barbee" was a motor-boat of light draught about thirty-two feet long, and twelve feet abeam, and was thus especially suited to navigating those waters. She had been generously furnished for the cruise by $\mathrm{Mr}$. Charles Deering, and it should be mentioned that it was Mr. Deering's deep interest in the expedition that was the foundation of its success.

interests of the United States National Herbarium. He was at Cape Sable in the spring of 1891 . He died at Bradentown, September 20, I918.-J. H. B. 
Simultaneous with our departure was the advent of a "norther." The strong north wind stirred up a rough sea, and consequently a large part of the first day was spent in keeping our food supply and collecting-outfit out of reach of the water which came in over the decks as we proceeded southward. The end of the first day found us in the shelter of Jewfish Creek, which is about midway between the northern and southern ends of Key Largo. The strength of the "norther" continued, but during the second day we made our way southward through Blackwater Sound and Tarpon Basin and then entered the Bay of Florida. There we anchored between Lignum Vitae Key and Lower Matecumbe Key and in this shelter awaited the falling or the shifting of the wind.

During this delay we made collections on Lignum Vitae Key, where we discovered a prickly-pear new, apparently, to science; on Lower Matecumbe Key, where we found a tree cactus related to the endemic Cephalocereus keyensis of Key West and later described as Cephalocereus Deeringii; ${ }^{4}$ and on Upper Natecumbe Key, which yielded a shrubby marsh-fleabane heretofore known in the United States only from Key West.

When the wind abated slightly we decided to try to reach Long Key and Vaca Key, instead of going directly to Cape Sable. However, as soon as we had gotten behind the banks that extend northward from near Lower Matecumbe Key we found smoother water, and headed the "Barbee" in the direction of Cape Sable. Soon after land had disappeared to the southward, Sandy Key came above the horizon to the northward. When oppo-

${ }^{4}$ Journal of the New York Botanical Garden 18: I99-203. 1917. 
site Sandy Key the wind shifted to the northwest, however, and once more we found ourselves in very rough water. This condition continued until we turned eastward south of Cape Sable and headed in the direction of the settlement of Flamingo. Situated on the southern shore of the Florida peninsula about eight miles east of the capes, Flamingo is the southernmost settlement on the mainland of the United States.

Having anchored off the settlement we devoted the late afternoon to collecting in the hammocks and on the prairies in the vicinity, and in the evening arranged for the coöperation of an old resident with his small motor boat to help us penetrate into the interior. At daybreak next morning we weighed anchor and proceeded eastward to the limit of deep water behind Joe Kemp's Key. There we transferred a supply of food and water to our fleet of three small boats, two of them with gasoline engines, and started for a place of uncertain geographical position known as Cuthbert Lake.

After proceeding eastward a short distance the water became very shallow, and as the tide went out our boats merely slid over soft mud covered with only a few inches of water. Our chartered boat went first. It was an excellent boat to lead and an easy one to follow. Every few seconds the motor would back-fire and discharge the resulting flame and smoke over the side of the boat. Thus, by day, we were led by "a pillar of cloud" and by night we could follow "a pillar of fire."

There we were introduced into a strange world. Not only orchids and bromeliads, but large cactus plants as well, grew everywhere on the trunks of both dead and 


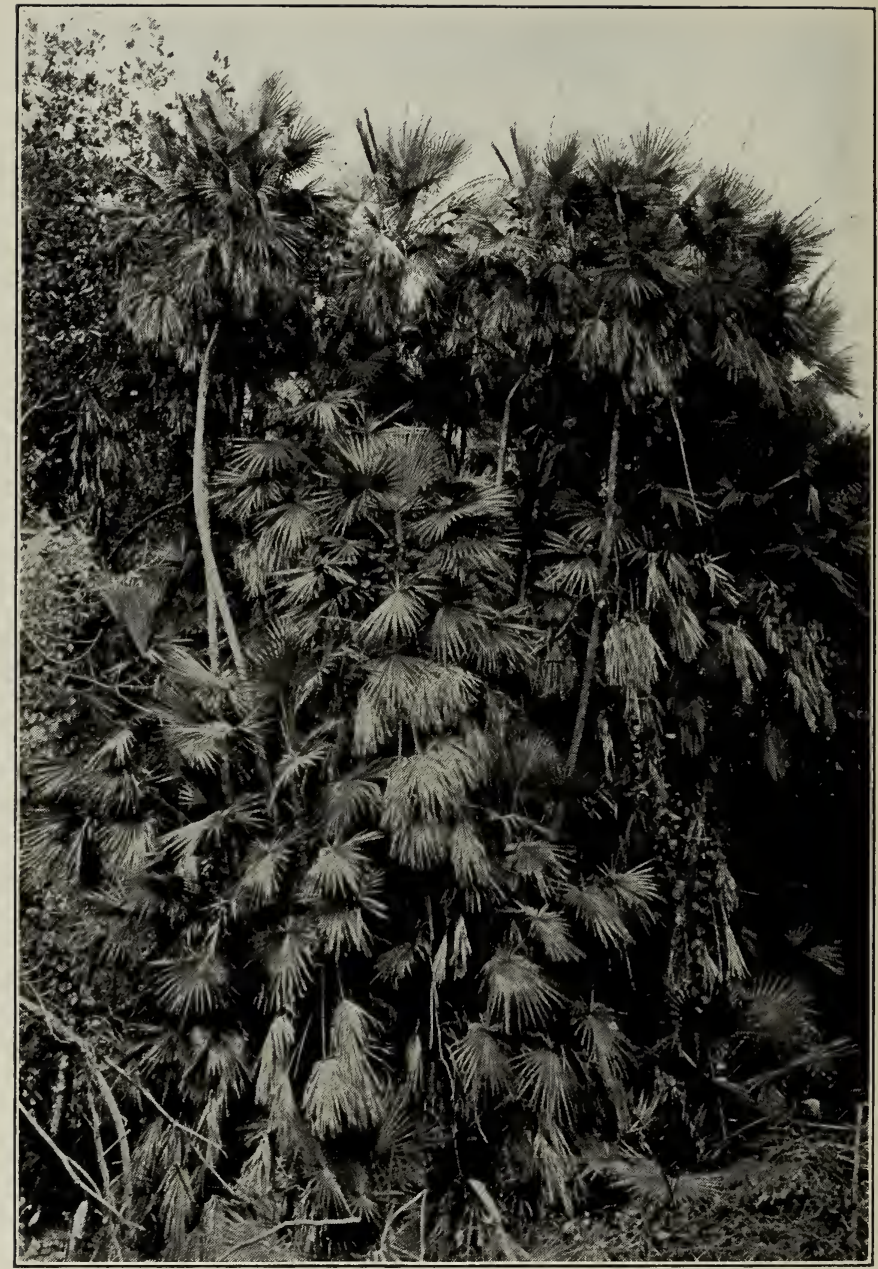

PLATE 2-Small colony of saw-cabbage palm in hammock near shore of Cuthbert Lake. Colonies of this palm often comprise scores or hundreds of stems so closely set as to be impenetrable. The new stems are stocky and leafy throughout; the older stems very slender and naked except for the terminal crown of leaves. The flower-stalks, in spring, are erect or ascending and project above the crown of leaves. In fall, the masses of bright-colored fruit-clusters constitute an impressive sight. 
living trees. Although there was little showy terrestrial vegetation, many of the air-plants were conspicuously beautiful. The butterfly-orchid (Cyrtopodium punctatum) was in full bloom. Most interesting was the large columnar cactus (Harrisia), with its erect, reclining, or climbing, hawser-like stems and branches, and large white flowers.

Once within the mangroves our course, for a distance of about six miles, lay through seven creeks and seven lakes. These were completely hidden one from another, and each concealed from the traveler until he was actually upon them. The creeks were natural channels of deep water; but their courses were tortuous and progress along them was much impeded by snags, beneath, on either side, and overhead. For a great part of the distance, therefore, we had either to lie down in the boats in order to save our heads or to get out and pull the boats over snags. But the lakes were beautiful, shallow, irregular bodies of crystal-clear salt-water. Their soft mud bottoms were almost completely covered with the most matted masses of sea-weeds I had ever seen. This "Brussels-carpet"-like growth of seaweeds came to within about six inches of the surface of the water and was so dense as to support a man walking.

Finally Cuthbert Lake was reached. This was a fine body of water completely surrounded by banks of beautiful green mangroves. There was some comparatively high land about the lake and there in the dense hammock we came upon one object of our incursion, namely, the saw-cabbage palm (Paurotis Wrightii), the least known and most distinctive of the palms of the eastern United 
States. This palm grows in small and large clumps or colonies. Sometimes between one hundred and two hundred stems stand closely together. The older stems, resembling stout fishing-poles, reach a height of over thirty feet, and around each clump of these, starting as suckers from their bases, arise new and shorter stems.

After securing as many palms and orchids as we could carry in our small boats through the creeks and lakes we started on the way back to the "Barbee." Darkness fell just as we emerged from the mangroves into the Bay of Florida and before we were half way to our destination. After proceeding a short distance both of our engines began to show signs of breaking down. Consequently we tied the three boats together so that we would not lose each other in the darkness and so that we could at least be sociable in case we should have to spend the night on the open sea in our leaky boats. The salt-spray on the exposed iron-work short-circuited the spark of the engines. Sometimes neither engine would work, sometimes one or the other would work for a while. The night was partly cloudy, but occasional glimpses of the stars enabled us to keep an approximate westerly course. We made haste slowly, however, and after considerable speculation and search we located before midnight a boat at anchor.

Urged to quick action by the chillness occasioned by the hours of the cold ride in wet clothes, every one boarded the craft, only to find that we had taken possession of the wrong boat!

On discovering our mistake we disembarked with unanimous spontaneity. The occupants of the boat were 



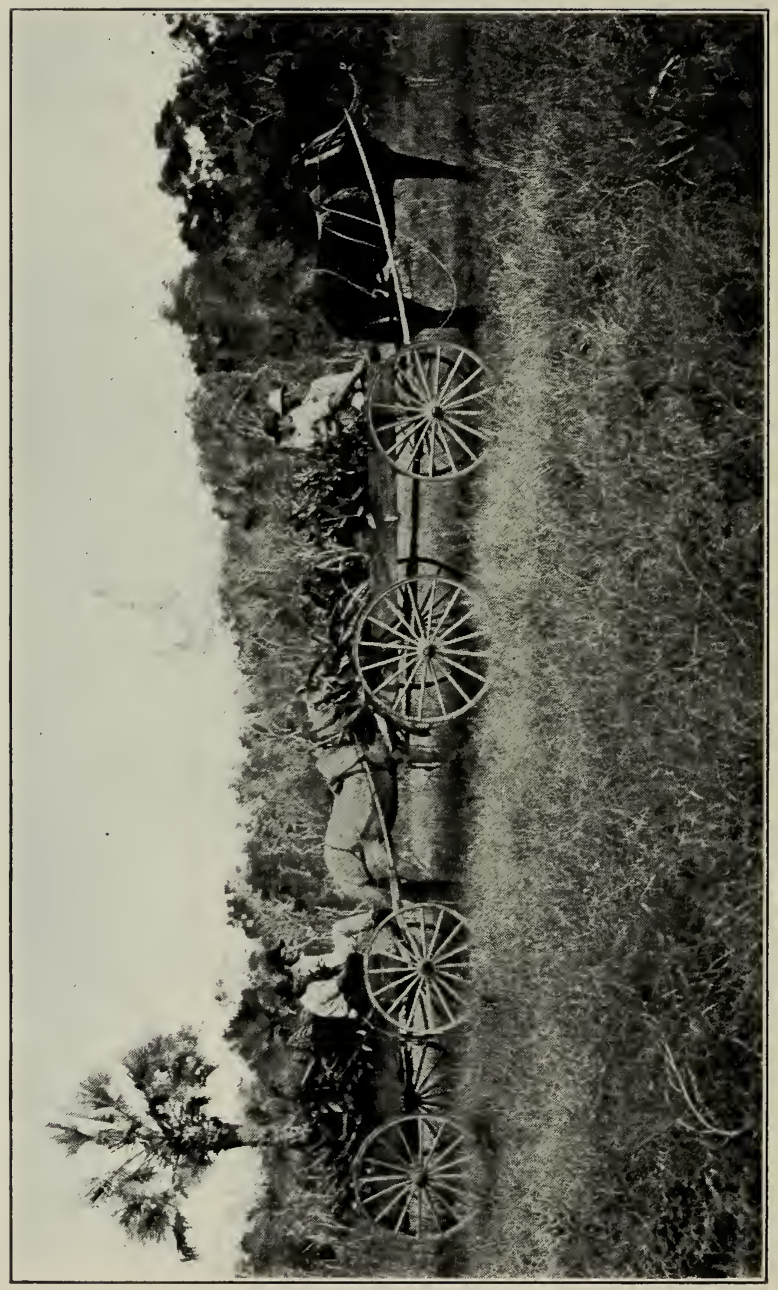

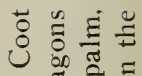

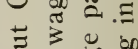

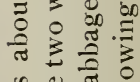

卷 $=$ ग

ह

ฮี่

$\cong$ 苾

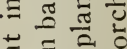

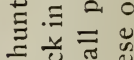

트

ปับ

क I

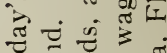

๘

¿ to

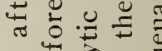

${ }_{\infty} \equiv \hat{\bar{E}} \Xi \Xi$

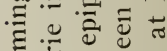

ह. E क

质尔莒

$\circ^{2} \stackrel{2}{=}$

的

छ $\frac{0}{\infty}$ के

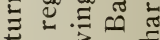

药

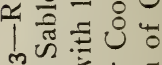

(ㄷㅏㄹㅀ

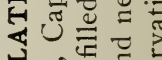

म 
perhaps as much surprised as we were, for no resistance was offered and no attempt at arrest for our apparent act of piracy was made. We could not escape as fast as we desired, for both of our engines now positively refused to work. However, we continued our search by rowing and poling, and in less than an hour we located another boat lying at anchor. After making sure, this time, that she was the "Barbee" we boarded her without further delay. Thus ended one of our most strenuous and exciting days.

Next morning at sunrise we went ashore, and with a horse and wagon in which to carry orchids, we set out for Coot Bay which lies in the wilderness about four miles northeast of Flamingo. This region is as different from that of Cuthbert Lake as any one could imagine; and the day turned out to be the greatest orchid-hunt in which any of us have ever participated.

After passing through stretches of beautiful prairic and strips of hammocks we entered Snake Hammock, which lies just south of Coot Bay. Unless some richer orchid locality is to be discovered in Florida, and that is possible, this hammock is the most marvelous natural orchid garden in the United States. All but one or two species of our epiphytic orchids grow there. They were not only there, but they grew in greater profusion and to greater size than I have ever seen them elsewhere. The most conspicuous orchid on account of size and flowers was Oncidium undulatum, which grew singly or in great masses; its leaves were $2-3$ feet long and often over $S$ inches wide. One plant of the butterfly-orchid ( $C$ yrtopodium punctatum) was found with thirty-one flower 
stalks, each about four feet long and bearing scores of blossoms. Among many other peculiarities that we noted in this hammock was the fact that the poison-wood, $\mathrm{Me}$ topium toxiferum, is replaced by another poisonous tree of another family, namely, the manchineel, Hippomane Mancinella.

Before we reached Coot Bay we had gathered two wagonloads of living orchids, for, as we were about to send our own wagon back to Flamingo, a party of hunters kindly turned an additional horse and wagon over to us. And both wagons were filled to capacity.

On the way back we temporarily deviated from the trail and penetrated the hammock to the westward towards Mud Lake. The further we went the more wonderful the hammock became and many interesting plants, particularly mosses and hepatics, were gathered here as well. It was late in the afternoon when we started westward and lack of time prevented us from pressing on further. Thus forced to return, we reached Flamingo after sundown and stowed our orchids in a shed.

The next day was devoted to exploration on Cape Sable proper. The cape consists of three blunt projections: namely, East Cape, Middle Cape, and Northwest Cape. These points are about five miles distant from each other. They are distinctive.

East Cape, which projects southward, is the most southern spot on the mainland of the United States, reaching almost to latitude $25^{\circ}$ north. Here the sanddunes are narrow, and back of these are considerable areas of hammock. The hammocks have grown up on old sand-dunes and the low hills have never been leveled. 
On the higher portions of the hills large trees occur, while in the depressions are numerous shrubs, and thickets of vicious cactus plants far more difficult to penetrate than barbed-wire fences and entanglements. The sand-dunes proper at East Cape are narrow and have a line of cocoanut trees along their edge near the beach.

It may be interesting to note here that there is a fivefoot or six-foot tide about Cape Sable and northward on the western coast, while there is only about half as much on the opposite side of the peninsula. The tide, too, runs around the cape like a mill-race. When we cast anchor at East Cape, the "Barbee," under the influence of the tide, stood with the stern against a strong gale and we were puzzled before learning the reason. The rushing of the tide past the cape doubtless accounts for the deep water close to the shore.

At Middle Cape, which projects southwestward, there are wide sand-dunes behind a fringe of cocoanut trees and the hammock is quite remote from the beach. There we were successful in finding Garber's-spurge (Chamaesyce Garberi), which was discovered there nearly half a century ago and apparently never collected there since. Another interesting find was the tuber-bearing pricklypear (Opuntia austrina) discovered at Miami some years ago.

The Northwest Cape projects westward. It has a rather steeply sloping beach and wide prairie-like sanddunes behind the treeless beach line, and then a narrow strip of hammock before the swamps are reached. On the sand-dunes occur grasses and sedges and considerable saw-palmetto and cabbage-palmetto, while in the ham- 
mock thatch-palms are exceedingly abundant. There is good evidence that the silver-palm (Coccothrinax argentea) once grew at this cape; but recent hurricanes have washed away large areas where it probably occurred. However, further exploration may yet bring it to light.

One of the numerous interesting features of the Cape Sable region is the mingling of the flora of the Everglade Keys and that of the Lower Florida Keys. The cape is on a direct line between Miami and Key West. There is good evidence that there was once a land connection from the Miami River region, which represents the northern end of the Everglade Keys, southwestward to Key West.

Towards the upper part of this cape we found a beautiful black-mangrove swamp back of the hammock. This swamp resembles the one we found later back of Sawfish hole, and it may be that the two points are extremities of a continuous line of swamps. Just above Cape Sable the red-mangrove swamp comes to the water's edge and at the mouth of Shark River, about ten miles northward, the Ten Thousand Islands begin and extend as far as Cape Romano, a distance of about fifty miles. It seems to be the unanimous opinion of all who have been among these islands that instead of bearing the name they have, it should be the "Ten Million Islands."

As the sun was setting we started up the western coast, and darkness found us anchored back of Shark Point for the night. During the night the wind shifted to the northwest and the temperature fell. The forenoon of the next day was cloudy and misty as well. After a 



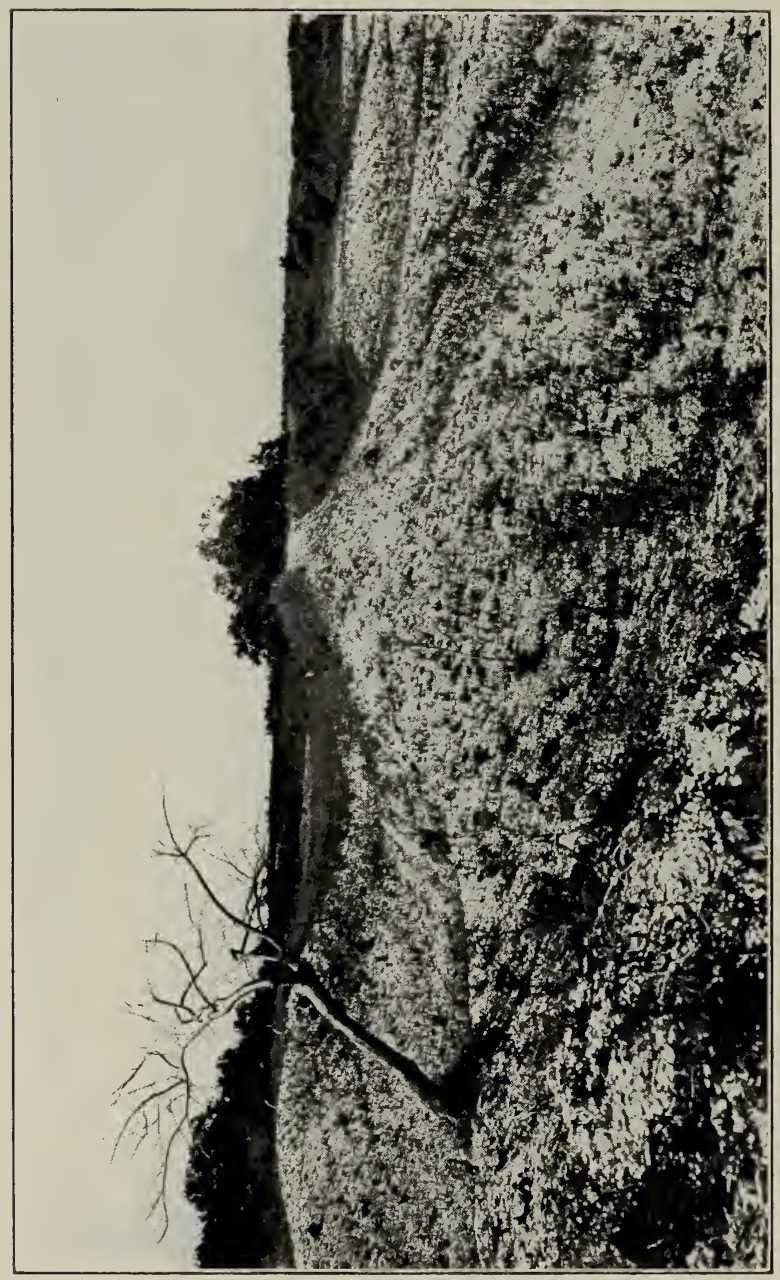

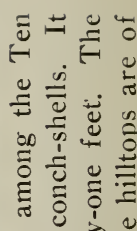

خ

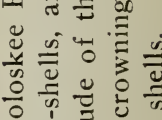

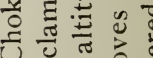

$\Xi$ क $\Xi$ क⿺

=

च

就

충

ป

.

$\sim \pm \stackrel{5}{0}$.

己

党 20

들

苟 $\frac{\pi}{\omega} . \Xi \frac{1}{1}$

워

릉

ป

$=\stackrel{\infty}{0} \pm$

I

$\forall \underline{m}=0$

되 들 호

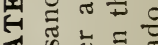

.

잉

E. 
rough passage of over itwenty miles northward, we located Chokoloskee Pass and found our way into Chokoloskee Bay about noon. We were fortunate in reaching this point at high-tide. In fact, we were fortunate in finding the pass at all without the help of a pilot. The entrance to the pass is very obscure, and the winding narrow channel leading from the ocean to Chokoloskee Bay is quite shallow and obstructed with oyster bars. However, we sailed directly into the bay and surprised the natives, some of whom came aboard and kindly directed us to a safe anchorage.

We at once went ashore to investigate Chokoloskee Island. The island is a kitchen midden. Similar middens of various sizes are common along and near the coast, especially north of Chokoloskee. They evidently represent the refuse heaps made by the aborigines of Florida. Utensils and implements may be found buried in these mounds and graves have been discovered in some of them. Trinkets of gold and silver, evidently brought to Florida by the early Spanish adventurers, have been dug up in some of the coastal middens. Chokoloskee is nearly circular, comprises a hundred and five acres, and has several elevations reaching twenty-eight feet and one altitude of thirty-one feet. It consists, from about the water-level to its maximum altitude, of shells, mainly. oyster-shells, clam-shells, and conch-shells. Most of the hammock that once clothed and adorned the island has been partially or wholly cut off. What hammock there is, is rather stunted, partly on account of the lack of finely disintegrated soil and partly due to its cxposed and wind-swept situation. The island, both in its regetation 
and settlement, is unique. The population numbers about one hundred souls, or in other words, there are about as many people as there are acres. They are all fisher-folk; and in addition, at seasons, decidedly inclined to ecclesiastical observances and celebrations.

We were surprised to find a number of tropical plants there. The island and Cape Romano, a few miles further north, represent the limit of most of the tropical vegetation on the western side of the Florida peninsula. One West Indian plant, a relative of our poke-weed, is known to occur in our flora only on Chokoloskee Island. The cat's-claw (Pithecolobium Unguis-Cati) and the caper-tree (Capparis jamaicensis) grew in abundance nearly everywhere in the hammock. Prickly-pears were ubiquitous, growing all the way from tide-water to the tops of the hills.

On the following day the region about the headwaters of the Chokoloskee River was our objective.

After crossing the bay our first stop was Turner Island, which is another kitchen-midden situated at the mouth of the Chokoloskee River. Here among other interesting plants we found one of our rarer lip-ferns, Cheilanthes microphylla, growing in the heaps of oystershells. The most conspicuous plant in bloom at that season was a kind of ragwort, or Senecio, with very brightyellow flower-heads. It occurred in great masses at many points on both sides of the river. As we ascended the river, stops were made at several small kitchenmiddens on the banks. The smallest kitchen-midden, and that nearest the head of the river, is known to the inhabitants of Chokoloskee and to hunters as Mt. Pleas- 
ant. It is a few inches above high-water and about large enough for pitching a small tent. Citrus trees were found naturalized on some of these small middens.

The river flows through prairie, hammock, and mangrove-swamps. Near its source the channel narrows down to a stream only a few feet wide and is almost hidden by the tall cat-tails. The source is a basin-like pond, which is, at low water, only about two rods wide.

Here we left our boats and made our way by an Indian trail across the prairie to the Tommy "Cypress," an area so called from an Indian named Tommy who once lived in the region. The "cypress" consists of areas of pine, palmetto, and cypress, and of hammock. We passed through interesting phytogeographic areas, one after another, until we entered a very large and dense hammock, where we were surprised to encounter many of the shrubs and trees common in the more northern portion of the Florida peninsula. We were, therefore, in a floral region wholly different from that we had left in the morning. At this point our party separated into two; the one followed the length of the hammock in one direction and the other went through prairie, pineland, and deep cypress-swamps in the other direction and finally encountered an Indian camp in the pine-forest. The hammock referred to lay in a slough. It was then dry, but marks on the tree-trunks showed that the water often stood about neck-deep. The largest and most plentiful tree was the cypress, but other broad-leaved deciduous trees were present, such as the ash (Fraximus) and maple (Acer). There were epiphytic orchids (Auliza, Ency'clicl) and epiphytic ferns, among which the tropical spleenwort 
(Asplenium serratum) was most plentiful and stood out most conspicuously as gigantic plants perched on the large tree-trunks. After several hours of interesting and profitable exploration and collecting, both parties met near the source of the Chokoloskee River, where we had left our boats.

The members of the other party encountered the pondcypress instead of the river-cypress of the slough. It is a smaller tree, supporting in its upper parts dense clumps of epiphytic orchids and several kinds of bromeliads or air-plants. The lower parts of the trunks often were host to large quantities of the tropical brush-like clubmoss-relative, Psilotum nudum. The prairies and open pine-woods were carpeted with various spring-blooming herbs with bright-colored flowers in whose corollas yellow, blue, and pink predominated.

Upon returning to the "Barbee," we weighed anchor and went several miles northward in order to investigate the kitchen-middens at Sand-fly Pass. The pass is evidently well-named, for the sand-flies soon found us. At sunset we returned to Chokoloskee Island and prepared for our homeward journey.

The following morning, on a low tide, we decided to go to sea, but after proceeding for a mile through the channel we ran on an oyster-bar. We deferred our departure, therefore, until we should have more water. When the tide did come in we made our way to the Gulf of Mexico, where we were greeted with a strong westerly gale and a sea so rough that we were compelled to eat our dinner off the floor of the boat instead of off the table. 


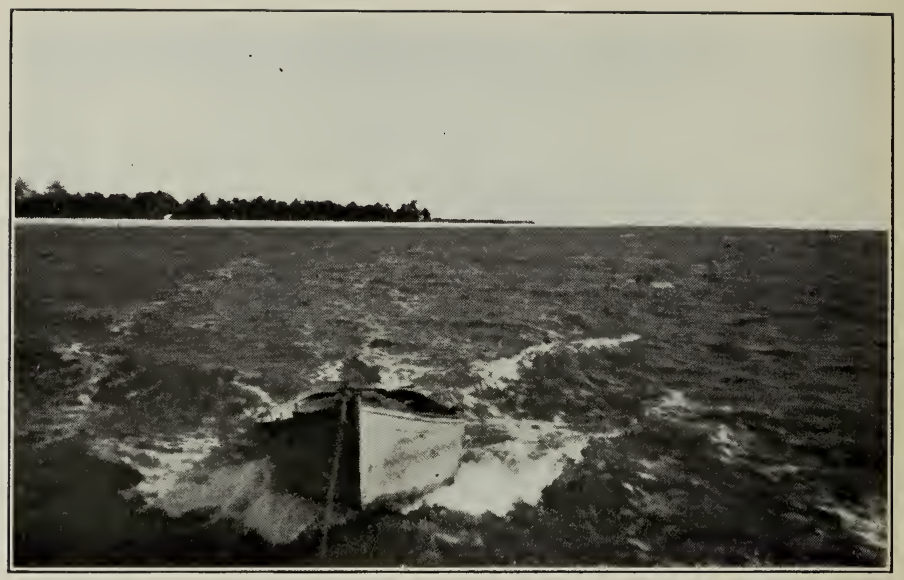

PLATE 5 A-Rounding Cape Sable. View from the stern of the "Barbee" while under way, passing from the Bay of Florida into the Gulf of Mexico. East Cape, the most southern point of the mainland of the United States, in the distance.

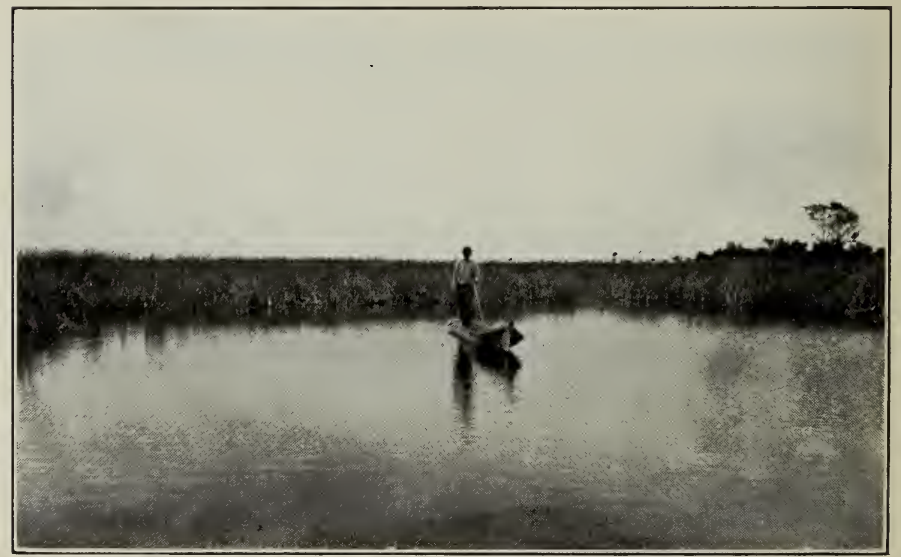

PLATE $5 \mathrm{~B}$-In the source of the Chokoloskee River, whence Indian trails lead to the interior. Basin, with Seminole Indian dugout canoe, in foreground. Prairie, covered with saw-grass and cat-tail, in background. 
Our next harbor was Lossman's Key, which is about half way between Cape Sable and Chokoloskee Pass. We made a landing on the island and searched for a reported hammock with royal-palms, but were unsuccessful in our quest. Returning to the "Barbee" we tried to locate the channel leading into Rodgers River. This river rises in the Everglades and flows through the Ten Thousand Islands into the gulf at the southern end of Lossman's Key. Darkness overtook us before we found the channel, however, so we anchored off shore for the night. The following morning before sunrise we started again in quest of our elusive river, this time in one of our small boats; and, having found it, proceeded with our exploration.

Once above the mouth of Rodgers River, as of similar rivers hereaouts, one finds a confusing maze of channels winding among myriads of mangrove-clad islands-altogether a labyrinth of the first order. But we ascended the river to a point where, instead of mangrove, the higher land supports hammock. There stately royalpalms rose to heights of over one hundred feet, conspicuously overtopping all other vegetation.

The channels here, and everywhere, were filled with myriads of oyster-bars. And although it was doubtless from some of these bars that the numerous ancient middens came into being, they still furnish an inexhaustible supply of oysters.

We returned to the "Barbee" about noon and started for Flamingo. We were soon at our destination, and delayed just long enough to readjust our cargo and load the large collection of orchids we had stored the previous 
week. When the cargo was made secure from damage by sun or salt-spray, we headed for Cape Sable again and before sunset cast anchor for the night in Saw-fish Hole, about three miles east of the cape. Here, an hour was devoted to collecting in the black-mangrove hammock, where more orchids and other interesting plants were found. The orchids, naturally, were epiphytic and the butterfly-orchid (Cyrtopodium) is the largest and most conspicuous. The level floor of the swamp was almost completely carpeted with a growth of the saltwort (Batis maritima), growing mostly about knee-high, and the leather-fern (Acrostichum aureum). Here and there, however, in striking contrast to the deep green of the saltwort, were shrubs or colonies of the maritime matrimony-vine (Lycium carolinianum) with its light green foliage, blue or lilac flowers, and strikingly red berries.

The following forenoon we started across the Bay of Florida, heading in the direction of Vaca Key, but a short stop was made at Sandy Key for collecting. This key, an isolated sand-bar about seven miles south of Cape Sable, supports considerable hammock. Among the interesting plants we found quantities of our rarest dewflower, the tropical Commelina elegans. Vaca Key we reached in due time, then Bamboo Key, ${ }^{5}$ and, when darkness found us, we were in a small bay behind Lower Matecumbe Key, from a point near which ten days previously we had left the keys for Cape Sable.

We landed on Lower Matecumbe Key the following

5 This island was visited by the writer on a cruise earlier in the year, and its vegetation was described in the Journal of the New York Botanical Garden 18: 107. 1917. 
morning and secured quantities of the rare cactus we had located there during the earlier part of our cruise. This plant, a species of Cephalocereus, with garlic-scented flowers, is nearly or quite similar to the one heretofore definitely known only from Key West. It was observed but not collected in a hammock on Lower Matecumbe Key several years ago by a member of our party.

Having devoted as much time as could be spared to this locality we moved on to Umbrella Key (Windlys Island) and Long Island. The former island is higher than the other keys, and most of it in the form of rock has gone to build the larger part of the Key West Extension of the Florida East Coast Railway. The main object of our visit to this island was to search for one of our rarest trees, the white-ironwood, Hypelate trifoliata. We were successful in finding a few trees in the small remnants of the once beautiful hammock. Some of these trees had a maximum trunk-diameter of fully two feet. Proceeding northward we reached Jewfish Creek about sundown and spent the night there. The next day was to find us safe in Miami.

It was after a period of five days, during which our living and dried specimens were cared for, that a cruise to the Madeira Bay region was undertaken. This, like the cruise just completed, was partly for the purpose of finding the saw-cabbage palm (Panrotis Wrightii). An early start on Saturday, April I 5, and a continuous r'tu1. without a stop of the engine, brought us to the mouth of Madeira Bay at the southern end of the Flor:da peninsula about on hour before sunset. This hour was deroted to exploring a hammock island near the mouth of the 
bay. There, as in all the neighboring hammocks, the mahogany or Madeira-redwood (Swietenia Mahagoni) is exceedingly common. The bay and hammock were long ago named for this tree, which occurs there both large and small. Many large trees were cut out long ago and many have been washed away from the everchanging shore line.

We started in two row boats at sunrise the following morning for the western end of the bay about two miles distant and soon located the palm we sought. We found it growing in great clumps, its fishpole-like stems commonly over thirty feet in height. The day we spent digging palms and exploring the Madeira hammock. Much of interest was encountered. There, the sugar-berry (Celtis mississippionsis) reaches its southernmost station. A representative of a group of tropical bonesets (Osmia frustrata), hitherto known only from the Florida Keys, was there in abundance. There, too, we found the large epiphytic cactus discovered in the Cuthbert Lake region. As far as it was observed, it always grew well above the ground on both living and dead tree-trunks. The dense hammock also yielded an apparently new vine, a kind of Tournefortia; but; unfortunately, it was devoid of both flowers and fruits. It is a pleasure to report the rediscovery of our rarest, and a showy, passion-flower (Passiflora pallens). It grew in great quantities, covering the trees with its variegated blossoms and pendulous green and purple fruits. This plant, it may be mentioned in passing, was once found in the now extinct Caldwell Hammock on the Everglade Keys. While in the Madeira hammock, we were only a few miles distant, as 


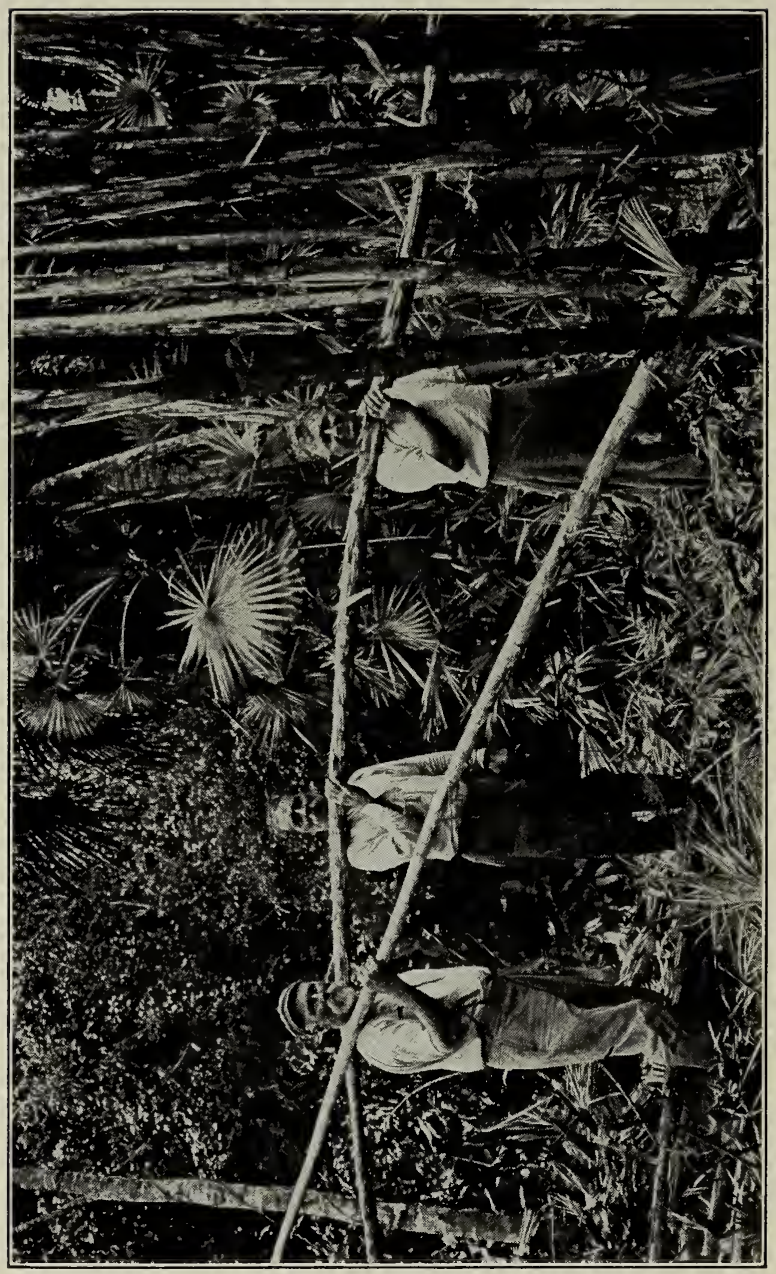

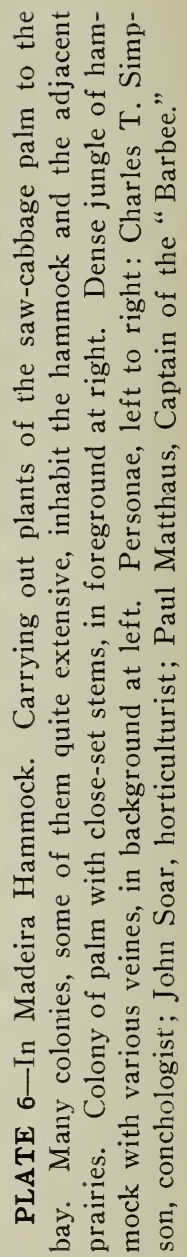


nearly as we can calculate, from a point at Cuthbert Lake that we had reached several weeks previously. Having secured and gotten aboard as many palms as could be carried across the bay in our small boats, we returned to the "Barbee" with some difficulty against a strong east wind which had freshened during our absence.

When, during the afternoon of the previous day, we were approaching Madeira Bay we had noticed that the hammock was on fire; indeed the following morning we had actually crossed smoldering areas. The rising east wind was now fanning into flame the smoldering embers. and, as we departed homeward across the Bay of Florida, we saw miles of hammock rolling skyward their clouds of black smoke. This calamity was not confined to the neighborhood of Madeira Bay, but in the Cape Sable region three or four vast forest fires were to be observed, and we could see smoke drifting for many miles to sea.

Forest fires, perhaps, were more frequent in southern Florida that year than usual; for beginning with the end of the preceding year, there had been a prolonged drought. Because of this the hammock both on the keys and on the mainland presented an unusual appearance. Shrubs and trees, that during normal seasons are never devoid of leaves, were completely bare; others had dropped a large proportion of their leaves, and of those still clinging nearly all, instead of standing in their normal position, were wilted and drooping. The floor of a hammock in tropical Florida is usually quite clean, as normally the trees drop their leaves gradually, and only after new leaves have developed. That April, however, those tropical hammocks resembled to a striking 
extent our northern woods in early winter, when fallen leaves lie a half-foot deep.

Collections of tree snails were made at nearly all landing places. These collections confirmed the ideas of the former distribution of land and ancient land connections on the Florida Reef previously worked out by C. T. Simpson, the conchologist of our party.

The following itinerary will show our movements during the cruise.

Localities printed in small capitals indicate points where collections of plants were made:

March 28. Miami to Jewfish Creek.

March 29. Jewfish Creek to Lignum Vitae Key, to Upper Matecumbe Key, to Lower Matecumbe Key.

March 30. Lower Matecumbe Key to Flamingo.

March 3I. Flamingo to Cuthbert Lake, and return. April I. Flamingo to Coot Bay, and return.

April 2. Flamingo to Cape Sable, East Cape, to

Middle Cape, to Northwest Cape, to Shark Point.

April 3. Shark Point to CHokoloskee Island.

April 4. Chokoloskee Island to TURner IsLAND, up to head of Chokoloskee River, to Tommy Cypress, Pineland, PraiRie, Hammock, to Sandfly Pass, to Chokoloskee Island.

April 5. Chokoloskee Island to Lossman's Key.

April 6. Lossman's Key to Rodgers River, to Flamingo. 
April 7. Flamingo to Cape Sable, to Sandy Key, to Vaca Key, to Bamboo Key, to Lower Matecumbe Key.

April 8. Lower Matecumbe Key to Umbrella Key, to Long IsLand, to Jewfish Creek. Creek.

April 9. Jewfish Creek to Pumpkin Key, to Sands KEY, to Miami.

\section{Supplementary Cruise}

April i5-I7. Madeira Bay and Madeira Hammock, southern end cf piniinsular Florid:.

The results of this reconnaissance revealed the need of more thorough exploration in the Cape Sable region before the advance of civilization changes or exterminates its primeval conditions.

A highway now under construction between Miami and Cape Sable will soon offer facilities for the further exploration of localities heretofore difficult of access from a boat; but, unfortunately, it will open the region to the inevitable advance of civilization with its accompanying unnecessary destruction and vandalism. 


\section{ANNOUNCEMENT}

\section{Descriptive Floras and}

\section{Miscellaneous Papers}

\section{By JOHN KUNKEL SMALL, Ph.D., Sc.D.}

Ferns of Tropical Florida-(Illustrated) . . . . . \$1.55

Contains descriptions with illustrations, and notes on the distribution and habitats of the ferns and fern allies of the Everglade Keys, peninsular Florida and the Florida Keys.

Ferns of Royal Palm Hammock-(Illustrated) . . . . . . \$0.50

Contains descriptions with illustrations, and notes on the habitats and distribution of the ferns of Royal Palm Hammock in the southern part of the Everglades, Florida.

Flora of the Southeastern United States. First Edition . $\$ 5.00$

Carriage extra

Contains descriptions of the seed-plants, ferns and fernallies growing naturally in North Carolina, South Carolina, Georgia, Florida, Tennessee, Alabama, Mississippi, Arkansas, Louisiana, and the Indian Territory, and in Oklahoma and Texas east of the one-hundredth meridian. Also analytical keys to the species and higher plant groups, habitats, and general geographical distribution .

Flora of the Southeastern United States. Second Edition,

revised and enlarged . . . . . . . . \$ \$4.00

Carriage extra

Flora of Miami . . . . . . . . . . . . . . . . \$2.15

Contains descriptions of the seed-plants growing naturally on the Everglade Keys and in the adjacent Everglades, southern peninsular Florida, with analytical keys to the species and higher plant groups. Habitats and extra-limital geographical distribution for the Florida Keys and West Indies are given. 
A hand book of the native and naturalized trees of Florida, with analytical keys to the species and higher plant-groups, notes on the habitats, and geographical distribution within the state, and reference to the continental and West Indian distribution of the species.

Flora of the Florida Keys

Contains descriptions of the seed-plants growing naturally on the islands of the Florida reef, from Virginia Key to Tortugas, with analytical keys to the species and higher plant-groups, habitats of the species and geograplical distribution, and reference to the occurrence of the species on the Everglade Keys and in the West Indies.

Shrubs of Florida . . . . . . . .

A hand-book containing descriptions of the native and naturalized shrubs of Florida, with analytical keys to the species and higher plant-groups. The habitats and geographical distribution of the species within the state are given, and reference is made to the occurrence of the species on continental North America and in the West Indies.

Flora of Lancaster County . . . . .

Contains descriptions of the seed-plants growing naturally in Lancaster County, Pennsylvania. A field-book with analytical keys to the species and higher plant groups, habitats, and geographical and geological distribution of species. (In collaboration with J. J. Carter.)

\section{A Monograph of the North American Species of the Genus} Polygonum

Contains descriptions of the species of the genus Polygonum growing naturally in North America, with analytical keys. Quarto, with 178 pages, and 84 full page plates, 69 plates illustrating the species, and 15 plates illustrating the comparative anatomy of the stem.

The Cape Sable Region of Florida-(Illustrated) . . . . . \$0.50

A popular account of the country and the vegetation of the Cape Sable region of Florida.

Renit by P. O. or Express Money Order, or Draft on N. Y Subscriptions may be sent to

\section{JOHN K. SMALL}










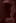

3ind

23

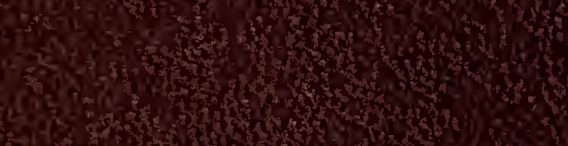

3.

Now

a

Oris

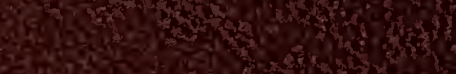

9.

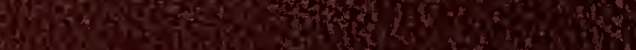

S.

STat

350.

蕰

7.

intory

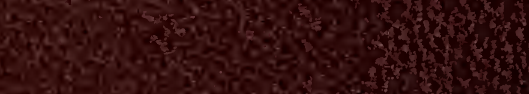

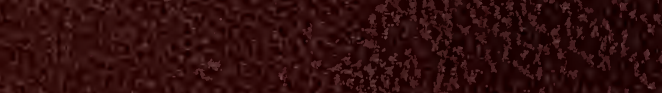

5 -

5.7.

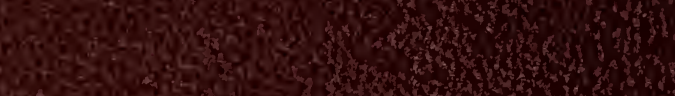

Oon

5.

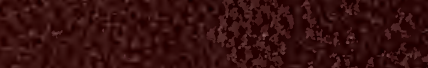

STing

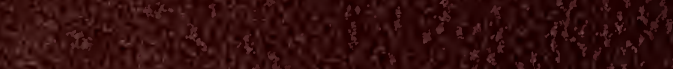

(x)

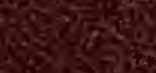

Thy

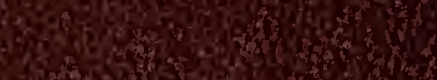

Whes

3.

H.

4.

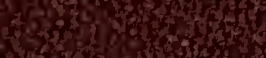

How 